\title{
Intraclass reliability of the Alberta Infant Motor Scale in the Brazilian version
}

\author{
CONFIABILIDADE INTRACLASSE DA ALBERTA INFANT MOTOR SCALE NA VERSÃO \\ BRASILEIRA
}

\section{LA CONFIBILIDAD INTRA-CLASE DE ALBERTA INFANT MOTOR SCALE EN LA VERSIÓN BRASILEÑA}

\section{Larissa Paiva Silva1', Polyana Candeia Maia², Márcia Maria Coelho Oliveira Lopes ${ }^{3}$, Maria Vera Lúcia Moreira Leitão Cardoso ${ }^{4}$}

\begin{abstract}
This study had as its objective to analyze the intraclass reliability of the Alberta Infant Motor Scale (AIMS), in the Brazilian version, in preterm and term infants. It was a methodological study, conducted from November 2009 to April 2010, with 50 children receiving care in two public institutions in Fortaleza, Ceará, Brazil. Children were grouped according to gestational age as preterm and term, and evaluated by three evaluators in the communication laboratory of a public institution or at home. The intraclass correlation indices for the categories prone, supine, sitting and standing ranged from 0.553 to 0.952 ; most remained above 0.800 , except for the standing category of the third evaluator, in which the index was 0.553 . As for the total score and percentile, rates ranged from 0.843 to 0.954 . The scale proved to be a reliable instrument for assessing gross motor performance of Brazilian children, particularly in Ceará, regardless of gestational age at birth.
\end{abstract}

\section{DESCRIPTORS}

Child development

Measures

Psychometrics

Reproducibility of results

Nursing

\section{RESUMO}

Objetivou-se analisar a confiabilidade intraclasse da escala Alberta Infant Motor Scale (AIMS), na versão brasileira, em crianças pré-termo e a termo. Estudo metodológico, realizado de novembro de 2009 a abril de 2010, com 50 crianças atendidas em duas instituições públicas de Fortaleza, Ceará, Brasil. As crianças foram agrupadas conforme a idade gestacional em pré-termo e a termo e avaliadas no laboratório de comunicação de uma instituição pública ou em domicílio por três avaliadores. Os índices de correlação intraclasse para as categorias prono, supino, sentado e em pé variaram de 0,553 a 0,952, mantendose em sua maioria acima de 0,800 . Apenas no item em pé do terceiro avaliador o índice foi 0,553 . Quanto ao escore total e ao percentil, os índices variaram de 0,843 a 0,954 . A Escala mostrou-se um instrumento confiável para avaliar o desempenho motor grosso de crianças brasileiras, particularmente as cearenses, independente da idade gestacional ao nascer.

\author{
DESCRITORES \\ Desenvolvimento infantil \\ Medidas \\ Psicometria \\ Reprodutibilidade dos testes \\ Enfermagem
}

\begin{abstract}
RESUMEN
El objetivo fue analizar la confiabilidad intra-clase de Alberta Infant Motor Scale (AIMS) en la versión brasileña, en niños pre-término y a término. Estudio metodológico, realizado de noviembre de 2009 a abril de 2010, con 50 niños atendidos en dos instituciones públicas de Fortaleza/ Ceará/Brasil. Los niños fueron agrupados, según la edad gestacional, en pretérmino y término y evaluados en un laboratorio de comunicación de una institución pública o en sus domicilios, por tres evaluadores. Los índices de correlación intra-clase para las categorías prono, supino, sentado y de pie variaron de 0,553 hasta 0,952 , manteniéndose en su mayoría encima de 0,800 y sólo en el ítem de pie del tercer evaluador, el índice fue 0,553. Mientras que en el Score total y el Percentil, hubo una variación de 0,843 hasta 0,954 . Se concluye que la escala es un instrumento confiable para evaluar el rendimiento motor grueso de niños brasileños, en particular de Ceará, independientemente de la edad gestacional al nacer.
\end{abstract}

\author{
DESCRIPTORES \\ Desarrollo infantil \\ Medidas \\ Psicometría \\ Reproducibilidad de resultados \\ Enfermería
}

\footnotetext{
1 Nurse. Master's Student, Graduate Program in Nursing, Universidade Federal do Ceará. Fellow FUNCAP. Fortaleza, CE, Brazil. larissapaiva 87@hotmail.com 22Enfermeira. Master's Student, Graduate Program in Nursing, Universidade Federal do Ceará. Fellow FUNCAP. Fortaleza, CE, Brazil. polly_can_maia@hotmail.com ${ }^{3}$ Nurse. Doctorate in Nursing. Nurse, Assis Chateaubriand Maternity School of the Universidade Federal do Ceará. Fortaleza, CE, Brazil. enf.marcya@gmail.com ${ }^{4}$ Nurse. Doctorate in Nursing. Associate Professor, Department of Nursing, Universidade Federal do Ceará. CNPq-1D. Fortaleza, CE, Brazil. cardoso@ufc.br

$1\left(\begin{array}{cl}\text { Rev Esc Enferm USP } \\ 2013 ; \text { 47(5):1046-51 } \\ \text { www.ee.usp.br/reeusp/ }\end{array} \quad \begin{array}{ll}\text { Received: } 02 / 25 / 2012 \\ \text { Approved: } 06 / 05 / 2013\end{array}\right.$
}




\section{INTRODUCTION}

Brazil grows in the use of scales for the evaluation of infant growth and development, and many of the observed variables for each of these can be used in specific areas of development.

The majority of the assessment instruments used in nursing practice, education and research are developed in countries with different sociocultural realities distinct from those in which the instruments are applied, which highlights the importance of a judicious process of translation and adaptation, in order to minimize differences in the search for cultural equivalence and validity in the new population. Ideally, however, would be the development and validation of Brazilian instruments, as portrayed in some more recent studies ${ }^{(1-2)}$.

The development and validation of instruments involve the application of psychometric tests after their assessment, in order to answer some questions inherent to the process of validation, such as: does the test achieve the proposed objective? Are the final results of the measurement reliable? Thus, it becomes possible to know the primary qualities of instruments, such as reliability and validity ${ }^{(3)}$.

The assessment process involves the use of a valid, effectively designed instrument, adaptation for a specific population, a favorable environment, and, especially, an evaluator capable of recognizing the dynamics of motor development, pediatric motor skills and how they can be improved, to observe and quantify results, and to identify positive attributes of movement and not only its limitations ${ }^{(4)}$.

The monitoring of child growth and development was one of the basic health strategies prioritized after 1984 , that has demonstrated proven efficacy ${ }^{(5)}$. Such monitoring should occur from the moment of conception, during prenatal care, and continue during the first year of a child's life, aiming at early detection of possible complications and deviations, which can be corrected in infancy.

The premature infant that has not achieved adequate intrauterine development, presents functional and structural immaturity of the organs and systems, and, as a result, can present a pattern of motor development qualitatively different from the full term newborn, differences that seem to persist over the first years of life. The importance of monitoring of a premature infant was therefore considered, since prematurity is a risk factor for developmental delays. Furthermore, with technological advances existing within Neonatal Intensive Care Units (NICU), the newborn preterm infants (NBPTI) have shown increased rates of survival and could present lower neuro-sensorymotor development than term infants ${ }^{(6-7)}$.

In this process, emphasis is on the nurse as having communication as a work tool in his therapeutic implementation, which promotes greater client interaction, using both the verbal and nonverbal channels. Such interaction between nurse and client allows a more open relationship, even among professionals and parents, who often remain inhibited and do not reveal information important to the process of child development.

Non-verbal communication is the transmission of messages through the body, facial expressions, interpersonal distances maintained, objects and adornments used, among others ${ }^{(8)}$ The effectiveness of communication can be increased with the recognition of the importance of body language, particularly with regard to proximity, posture and eye contact, not only in relationship to the child, but with the team and the family ${ }^{(9)}$. This is usually possible, in a comprehensive manner, when conducting home visits in the community.

Home care integrates the Family Health Strategy (FHS) as a form of access to professional performance in community health and home care, the living environment for patients and families, providing a group of planned and sustained ambulatory activities, developed at home, and that can be manipulated by the home visit or hospitalization ${ }^{(10)}$.

Among the assessment tools, the Alberta Infant Motor Scale (AIMS) has been used in several studies in Brazil, and it is considered useful in practice in the evaluation of motor development in preterm infants from the monitoring programs of the Brazilian public health system ${ }^{(11)}$.

It is a scale composed of figures distributed in four different positions: prone, supine, sitting and standing, which can be used in children from birth to 18 months of age ${ }^{(12)}$. It can be applied by professionals in pediatric health care who have knowledge of normal infant motor development, and practice in the application of the instrument. It was translated into Portuguese in 2007, as a postdoctoral activity of one of the authors.

However, it is necessary to verify the psychometric properties of this scale, as satisfactory levels of validity and reliability of an assessment instrument are not guaranteed when used in a culturally different population from that for which it was developed ${ }^{(13)}$.

Thus, this study aimed to analyze the intraclass reliability of AIMS, the Brazilian version of the Alberta Infant Motor Scale (Escala Motora Infantil de Alberta - EMIA), in full term and preterm newborns in Ceará. 


\section{METHOD}

This was a methodological and quantitative study, in which participated 50 children discharged from the neonatal unit of low and medium risk and/or were in the rooming-in system in a reference maternity hospital of Fortaleza-CE, as well as children enrolled in pediatric nursing consultations in the Family Development Center (FDC) from the Federal University of Ceará (Universidade Federal University do Ceará - UFC).

The sample was a convenience sample, recruited consecutively, which was based on the inventory of the entire population accessible at one time. The selected children were randomly divided into two groups with an equal number of participants (25) and the age of four months. For the group of full term newborns, chronological age (ChrA) was used and for those born prematurely, the corrected age was used (CA).

The eligibility criteria were: children at four months of age, CA or ChrA, with a gestational age of more than 32 weeks, with or without hospitalization in the neonatal unit, without congenital malformation, cerebral palsy or intraventricular hemorrhage. The exclusion criterion was the child's participation in a motor stimulation program.

Data collection occurred from November to December of 2009, and from January to April of 2010. The children were identified by means of a search of the medical and statistical archives (SAME) of maternity and those attending the FDC. After this phase, the parents or guardians of the children were contacted by telephone and invited to participate in the study, and the evaluation was scheduled based on their availability and that of the evaluators.

The evaluations were conducted by three examiners who were previously trained on the use of the scale, two nursing students and one nurse, and occurred at the Laboratory of Health Communication (LabCom-Health) of the Department of Nursing, UFC, or in the home, in the presence of parents or guardians of the children.

The EMIA, the Portuguese version of AIMS, was used as the instrument of data collection. It is a purely observational scale of infant motor performance, composed of 58 items divided into four subscales, each of which is determined by a basic posture: prone (21 items), supine (nine items), sitting (twelve items) and standing (sixteen items), ordered into drawings according to the stages of development of each subscale.

During the assessment, the examiner should observe the child's movement, on each of the basic postures, considering the aspects of motor performance, such as weight bearing, posture and antigravitational movements. The application of the test lasts 20 minutes, on average. The score is based on a dichotomized choice for each item, which must be reported as observed or not observed. Each observed item in the repertoire of motor skills of the child receives a score of 1 (one) and each item that is not observed receives a score of 0 (zero). The observed items in each of the subscales are summed, resulting in four subtotals (prone, supine, sitting and standing). The total score of the test is given by the sum of the subtotals obtained for each subscale. At the end of the evaluation, a total score from 0 to 60 points was credited, with the maximum score, 58 , that was converted into percentiles, ranging between 5-90\%, based on the established normative sample of the test with Canadian children ${ }^{(14)}$.

In order to investigate the psychometric property of intraclass reliability, with parental permission, the assessment of each child was videotaped. Blinding of the evaluators was used, in which each one recorded the score assessed for each child. This was done in an effort to test reliability through the correlation of the scores of the assessment as it was originally completed, and then with the videotape of the child, which was seen and reassessed by the same investigators 30 days after the initial assessment.

Reliability is used to analyze whether a scale reflects the construct it is measuring and, therefore, the fulfillment of the same questionnaire at two different times must be observed and the result should be similar, so that it is considered reliable ${ }^{(15)}$.

The statistical software program, Predictive Analytics SoftWare (PAWS), version 18, was used for storage and data analysis. Descriptive statistics were used for continuous variables such as the mean, median and standard deviation. To assess intraclass reliability, the intraclass reliability coefficient (ICC) was used.

The study was approved by the Ethics in Research Committee at the institutional locus of the study, conforming to protocol number 085/09. Parents/guardians signed the Terms of Free and Informed Consent form (TFIC).

\section{RESULTS}

Of the 50 infants evaluated, 25 were full term and 25 preterm; 24 (48\%) were female and 26 (52\%) male. Thirtyseven (74\%) were discharged from hospital and 13 (26\%) were from the FDC.

The gestational age of the infants evaluated ranged from 32 to 41.8 weeks, with a mean of $36.88 \pm 3$ weeks. The weight of the infants ranged from 1095-4085 grams, with a mean of $2567.7 \pm 864$ grams, and a length of 35 to $55 \mathrm{~cm}$, with a mean of $45.8 \pm 4.5 \mathrm{~cm}$.

The ages of the infants ranged from 123 to 196 days, with a mean of $151.7 \pm 22$ days, however, when analyzing the ages separately, it was observed that the full term infant ages varied from four months and three days (123 days) to four months and 21 days (141 days), with a mean of four months and twelve days (132 days). The
Intraclass reliability of the Alberta Infant Motor Scale in the Brazilian version Silva LP, Maia PC, Lopes MMCO, Cardoso MVLML 
chronological age of the preterm infants varied from five months and three days (153 days) to six months and sixteen days (196 days), with a mean of five months and 21 days (171 days), while the corrected age ranged from four months ( 120 days) to four months and 25 days (145 days), with a mean of four months and ten days (130 days).

The children were examined in a unique moment, $33(66 \%)$ assessments were conducted in the LabCom Health/UFC and 17 (34\%) at home. The duration of each recording lasted a mean of eighteen minutes for evaluation.

Table 1 describes the intraclass reliability indices of the categories of the AIMS (prone, supine, sitting and standing) between the first evaluation and the evaluation of the recording, conducted by each of the evaluators.

Table 1 - Intraclass reliability of the AIMS categories between the first evaluation and the evaluation of the recording of the sample. Fortaleza, Brazil, November 2009 to April 2010.

\begin{tabular}{lcccc}
\hline Category & Prone* $^{*}$ & Supine* $^{*}$ & Sitting* & Standing* \\
\hline Evaluator 1 & 0,952 & 0,929 & 0,851 & 0,832 \\
Evaluator 2 & 0,883 & 0,895 & 0,773 & 0,662 \\
Evaluator 3 & 0,874 & 0,703 & 0,613 & 0,553 \\
\hline
\end{tabular}

* Intraclass coefficient of reliability, with reliability index of $95 \%$.

The first evaluator obtained reliability indices above 0.800 in all categories, with 0.952 for the prone, 0.929 for supine, 0.851 for sitting and 0.832 for standing categories. The second evaluator had an index of 0.883 for the prone, 0.895 for supine, 0.773 for sitting and 0.662 for standing categories. The third evaluator obtained an index of 0.874 for the prone, 0.703 for supine, 0.613 for sitting, and 0.553 for standing.

Table 2 presents the intraclass reliability indices of the AIMS results (total score and percentile) between the first evaluation and the evaluation of the recording, conducted by three evaluators.

Table 2 - Intraclass reliability of the AIMS results, between the first evaluation and evaluation of the recording of the sample. Fortaleza, Ceará, Brazil, November 2009 to April 2010

\begin{tabular}{lcc}
\hline Category & Total score * & Percentile* \\
\hline Evaluator 1 & 0,954 & 0,873 \\
Evaluator 2 & 0,914 & 0,866 \\
Evaluator 3 & 0,884 & 0,843 \\
\hline
\end{tabular}

${ }^{*}$ Intraclass coefficient of reliability, with reliability index of $95 \%$.

According to the data presented in Table 2, the evaluators obtained intraclass reliability indices above 0.800 for the results of the AIMS, with indices of evaluator 1 equal to 0.954 and 0.873 , of the evaluator 2 equal to 0.914 and 0.866 , and of the evaluator $3,0.884$ and 0.843 for the total score and percentile ranking, respectively.

The final scores were classified into five percentiles ranges: 0-10 (atypical development), 11-25 (performance suspect), 26-75 (normal performance), 76-90 (very good performance) and 91-100 (excellent performance) ${ }^{(16)}$.

\section{DISCUSSION}

The children's age on the day of assessment was observed to have variations from 123-196 days of chronological age, but the corrected age of the preterm infants ranged from 120-145 days. For the evaluation of the gross motor development of premature infants in the first year of life, the corrected age had to be used, because this area of development seems to develop in accordance with the corrected age rather than chronological age, along with other developmental areas such as speech acquisition, for example ${ }^{(17)}$.

The assessments occurred mostly in the filming room of the LabCom Health/UFC, which provided an ample space for the children's comfort and freedom of movement while the evaluation was being filmed. The support and cooperation of parents were essential; they interacted with the evaluators and remained close to the child, facilitating the realization of the movements on the part of the child who, with the proximity of the parents, felt more secure and performed the movements promptly.

Types of interventions and their objectives have been a focus for some studies in recent years, highlighting how a baby can acquire and demonstrate motor skills when a task is offered in a suitable environment, especially in the presence of people with whom he is familiar ${ }^{(18-19)}$.

In the second evaluation, it was observed that in the scoring of the scale using the images, the process was performed more smoothly and slowly, since the video could be seen more often and in a more detailed form, contributing to a more reliable assessment of motor performance of the child.

Some studies have used the recording as a tool to observe the object of study in a more enhanced manner, since the recorded images often revealed details not observed in the act of recording, for reasons such as the position in which the evaluator was located, the speed with which the child performed the movement, among others ${ }^{(20-21)}$.

Regarding the reliability of the AIMS, the intraobserver coefficient correlation for the categories of prone, supine, sitting and standing remained mostly above 0.800 , and only one index was below 0.600 . The indices of the results of the AIMS (total score and percentile), all remained above 0.800 .

The intraclass reliability refers to the level at which the evaluator replicates the measurement of the variable with similar scores, repeatedly. It is considered a satisfactory degree of agreement when the coefficient is between 0.600 and 0.800 ; low when it is below 0.600 ; and, excellent when it is above $0.800^{(22)}$. Thus, the results of this study demonstrated a satisfactory degree of agreement, reflecting the reliability of the AIMS scale.

A study that used the AIMS revealed that the rate of intraobserver reliability demonstrated strong concordance between the scores, with values ranging from 0.915 to $0.993^{(23)}$. The intra-evaluator index of $82.84 \%$ was 
obtained $^{(24)}$. However, the intraobserver correlation index was demonstrated only for one evaluator in both studies, and not for the three evaluators. By taking as a parameter only the first evaluator, the similarity between the referenced data was noted, as the indexes in this study ranged from 0.832 to 0.954 , considerable agreement.

Another study evaluated the internal consistency of AIMS in the Brazilian version using the Cronbach's alpha reliability coefficient and obtained the following results: prone $=0.86 ;=0.89$ supine; sitting $=0.80$; and standing $=$ 0.85 , considered excellent indices ${ }^{(23)}$.

A study conducted with a gaucho population to validate the Brazilian version of the AIMS scale showed excellent indices of content validity and demonstrated strong agreement among the evaluators (ICC between 0.86 and 0.99 ), high indices of reliability, corroborating the findings of this study ${ }^{(24)}$.

Research recently conducted in the southern region of the country using the Brazilian version of the AIMS scale to assess the gross motor development of children in public kindergartens, highlighted the importance of a positive environment, which acted as a facilitator of normal development ${ }^{(25)}$.

\section{CONCLUSION}

The AIMS scale can be applied to evaluate the gross motor performance of full term and preterm Brazilian

\section{REFERENCES}

1. Novato TS, Grossi SAA, Kimura M. Adaptação cultural e validação da medida "Diabetes Quality of Life for Youths" de Ingersoll e Marrero para a cultura brasileira. Rev Latino Am Enferm. 2008;16(2):224-30.

2. Carpes MF, Mayer AF, Simon KM, Jardín JR, Garrod R. Versão brasileira da escala London Chest Activity of Daily Living para uso em pacientes com doença pulmonar obstrutiva crônica. J Bras Pneumol. 2008;34(3):143-51.

3. Erthal TCS. Manual de psicometria. 4aed. São Paulo: Jorge Zahar; 1998.

4. Valentini NC, Barbosa MLL, Cini GV, Pick RK, Spessato BC, Balbinotti AA. Teste de desenvolvimento motor grosso: validade e consistência interna para uma população gaúcha. Rev Bras Cineantroprom Desempenho Hum. 2008;10(4):399-404.

5. Brasil. Ministério da Saúde; Secretaria de Políticas de Saúde. Atenção humanizada ao recém-nascido de baixo peso: método mãe-canguru. Brasília: MS; 2002.

6. Formiga CKMR, Linhares MBM. Assessment of preterm children's early development. Rev Esc Enferm USP [Internet]. 2009 [cited 2011 Dec 12];43(2):472-80. Available from: http://www.scielo.br/pdf/reeusp/v43n2/en_a30v43n2.pdf infants, with appropriate attention to the corrected age of preterm infants.

The results of this study may reflect the practice of educators and health professionals, since the confirmation of the reliability of the scale can encourage them to use it in their daily practice, as an important intervention in the child development process. The importance of using reliable instruments that guarantee reliable measure of infant motor behavior is also noted, contributing to the practice of the multidisciplinary team.

The Portuguese version of the scale is valid and reliable to be applied in Brazil, not only with children of Ceará, since the obtained reliability indices of scale was excellent, both in the present study as in recent studies conducted in other regions of the country. In one of these the scale was applied in the Brazilian version, translated by these authors, and the other was used in the original Canadian version, as presented in the discussion section on the data.

Studies in other regions of Brazil, not yet studied, are suggested, since there are large socioeconomic, educational and cultural differences in the country. In this way, a more profound insight into the use of the scale in Brazil could be achieved, as well as a higher contribution to the validity of the Portuguese version.
7. Farias LM, Cardoso MVLML, Oliveira MMC, Melo GM, Almeida LS. Comunicação proxêmica entre a equipe de enfermagem e o recém-nascido na Unidade Neonatal. Rev RENE. 2010;11(2):37-43.

8. Souza RB, Silva MJP, Nori A. Pronto-Socorro: uma visão sobre a interação entre profissionais de enfermagem e pacientes. Rev Gaúcha de Enferm. 2007:28(2):242-9.

9. Farias LM, Cardoso MVLML, Silveira IP, Fernandes AFC. Comunicação proxêmica entre mãe e recém-nascido de risco na unidade neonatal. Rev RENE. 2009;10(2):52-7.

10. Giacomozzi CM, Lacerda MR. A prática da assistência domiciliar dos profissionais da Estratégia de Saúde da Família. Texto Contexto Enferm. 2006;15(4):645-53.

11. Almeida KM, Dutra MVP, Mello RR, Reis ABR, Martins PS. Validade concorrente e confiabilidade da Alberta Infant Motor Scale em lactentes nascidos prematuros. J Pediatr. 2008;84(5):442-8.

12. Piper MC, Darrah J. Motor assessment of the developing infant. Philadelphia: Saunders; 1994.

13. Behling O, Law KS. Translating questionnaries and other research instruments: problems and solutions. Thousand Oaks: Sage; 2000. 
14. Maccoy SW, Bowman A, Smith-Blockley J, Sanders K, Megens AM, Harris SR. Harris infant neuromotor test: comparison of us and Canadian normative data and examination of concurrent validity with the ages and stages questionnaire. Phys Ther. 2009;89(2):173-80.

15. Field A. Descobrindo a estatística usando SPSS. $2^{2}$ ed. Porto Alegre: Artmed; 2009.

16. Castro AG, Lima MC, Aquino RR, Eickmann SH. Desenvolvimento do sistema sensório motor oral e motor global em lactentes pré-termo. Pró-Fono. 2007;19(1):29-38.

17. Lino PFM. Desempenho Motor em crianças pré-termo e a termo aos quatro, seis e oito meses de idade: estudo comparativo [dissertação]. Belo Horizonte: Escola de Educação Física, Fisioterapia e Terapia Ocupacional, Universidade Federal de Minas Gerais; 2008.

18. Willrich A, Azevedo CCF, Fernandes JO. Desenvolvimento motor na infância: influência dos fatores de risco e programas de intervenção. Rev Neurocienc. 2009;17(1):51-6.

19. Knoche L, Peterson CA, Edwards CP, Jeon HJ. Child care for children with and without disabilities: the provider, observer and parent perspectives. Lincoln: Early Childhood Research Quarterly; 2006.
20. Veturella CB, Zanandrea G, Saccani R, Valentini NC. Desenvolvimento motor de crianças entre 0 e 18 meses de idade: diferenças entre os sexos. Motricidade. 2013;9(2):3-12.

21. Pinto ESM, Lacerda CBF, Porto PRC. Comparação entre os questionários IT-MAIS e MUSS com vídeo-gravação para avaliação de crianças candidatas ao implante coclear. Rev Bras Otorrinolaringol. 2008;74(1):91-8.

22. Pereira MG. Epidemiologia: teoria e prática. Rio de Janeiro: Guanabara Koogan; 1995.

23. Valentini NC, Saccani R. Brazilian validation of the Alberta Motor Scale. Phys Ther. 2012;92(3):440-7.

24. Restiffe AP. O desenvolvimento motor de recém-nascidos pré-termo e a termo até a aquisição da marcha segundo Alberta Infant Motor Scale: um estudo de coorte [tese doutorado]. São Paulo: Faculdade de Medicina, Universidade de São Paulo; 2007.

25. Martinello M, Nazario PF, Marques LZ, Ries LGK, Lando C. Avaliação do desenvolvimento de lactentes matriculados em creches públicas. HU Rev (Juiz de Fora). 2011;37(2):155-62. 